\title{
Allelopathic Effects of Extracts from Maize Roots and Rice Husks' Residues on the Germination and Growth of Bidens pilosa $\mathrm{L}$.
}

\author{
Modupe Janet Ayeni ${ }^{1} \&$ Joshua Kayode ${ }^{1}$ \\ ${ }^{1}$ Department of Plant Science, Ekiti State University, Ado Ekiti, Nigeria \\ Correspondence: Joshua Kayode, Department of Plant Science, Ekiti State University, Ado Ekiti, Nigeria. Tel: \\ 234-803-506-3504. E-mail: jokayode@ymail.com
}

Received: January 21, 2013

Accepted: February 26, 2013 Online Published: March 15, 2013

doi:10.5539/jas.v5n4p146

URL: http://dx.doi.org/10.5539/jas.v5n4p146

\begin{abstract}
Screen house experiment was conducted to examine the allelopathic effects of the extracts from residues of maize root and rice husk on the germination and growth of Bidens pilosa L. The extracts brought about considerable inhibitions in all the growth parameters of the extract-treated seeds examined. The degree of retardation of both extract treated seeds increased with increase in the concentration of the extracts which showed that the inhibition was concentration dependent. The results obtained showed that the degree of retardation appeared to be more pronounced in $B$. pilos $a$ seeds treated with extract from maize roots in growth parameters such as number of leaves at harvest and leaf area, relative growth rates, dry roots and shoot weights were inhibited. Similarly the degree of retardation was more pronounced in rice husk extract-treated seeds in growth parameters such as germination percentage and speed of germination. Statistical analysis $(\mathrm{P}<0.05)$ revealed that there were significant differences in germination \%, dry shoot weights of $B$. pilosa seeds treated with $40 \mathrm{~g}$ and $50 \mathrm{~g}$ maize roots extract concentrations when compared to the control experiment while other concentrations showed no significant difference to control experiment. Also, speed of germination, number of leaves at harvest and leaf area of $B$. pilosa seeds treated with extracts from residues of maize roots showed significant differences when compared with the values obtained from the control experiments. However, there were no significant differences in the all the growth parameters with rice husk treated seeds compared to control experiments. Similarly, no significant difference was observed in the relative growth rate of $B$. pilosa seeds treated with maize root extracts compared to control experiments.
\end{abstract}

Keywords: allelopathy, maize root, rice husk, Bidens pilosa, inhibition

\section{Introduction}

The world population is expanding rapidly and there is need to increase food production to meet the food demand of the growing population of this millennium. The interference of weeds in agricultural fields greatly reduce crop yield thereby hindering the possibility of achieving the desired goal of food for all. The interference of one plant on the other by the release of biomolecules to the environment which affects and influence the growth and development of other plants and microorganisms either positively or negatively are termed allelopathy (Rice, 1984; Quassama, 2003; Khahn et al., 2009).

The biomolecules (allelochemicals) are biosynthesized secondary metabolites in plants such as tannins, flavonoids, alkaloids, terpenoids, coumarins and phenolic substances (Chaves \& Escudero, 2006; Khanh et al., 2007). Allelochemicals are present in virtually all plant parts including leaves, stems, roots, rhizomes, flowers, fruits, seeds and pollen grains (Ahmad et al., 2011) from where they are released to the environment through the process of leaching, volatilization, root exudation and decomposition of plant residues (Ben et al., 2001) which are capable of suppressing the growth of other plants. Allelopathic interference is one of the mechanisms for the successful establishment of invasive exotic weeds (Ridenour \& Callaway, 2001).

The manifestation of allelochemical in the recipient plant are shown to affect many different cellular processes in target organisms including disruptions of membrane permeability (Galindo et al., 1999), ion uptake, photosynthesis, respiration, crop water uptake are liable to disturbances by allelochemicals (Calera et al., 1995). These are shown in form of inhibited or retarded germination rate, reduced radicle or coleoptile extension, lack of root hairs, swelling of root tip, reduced dry weight accumulation and lower reproductive capacity (Ayeni et al., 1997). 
Bidens pilosa $\mathrm{L}$. is one of the major weeds in agricultural farms in South-Western Nigeria and its physiological characteristics made it an invasive plant which competes greatly with crops and reduced their yields. In Nigeria, allelopathic studies reported so far were skewed towards the allelopathic effects of weeds on agricultural crops. These included the studies of Gill et al. (1993) and Tijani- Eniola and Fawusi (1989) on Chromoleana odorata, Kayode and Adanlawo (1997) on Euphorbia heterophylla, Kayode (2004a and b) on Aspillia africana and Calotropis procera respectively.

Recently Ayeni et al. (2010) and Ayeni and Kayode (2011) reported the effects of some crops residues on weeds. These crop residues are often left uncared for in the fields after harvest. The aim of this investigation therefore is to examine the allelopathic potentials of residues from maize roots and rice husks on B. pilosa a weed widely spread in south western Nigeria.

\section{Materials and Methods}

A screen house experiment was conducted in the Department of Plant Science, Ekiti State University. Ado - Ekiti, Nigeria to examine the effects of maize root and rice husk of $B$. pilosa. Top soil to the depth of $10 \mathrm{~cm}$ depth was evacuated from regenerated vegetation on the University campus. The soil was sterilized at a constant temperature of $80^{\circ} \mathrm{C}$ for one hour to destroy the existence of unwanted and buried seeds in the soil. Maize root residues were obtained from the experimental farm of the department. Rice husks were obtained from a rice mill at Igbemo-Ekiti, a town situated at about $15 \mathrm{Km}$ from the University campus. The residues were air-dried for three weeks, pounded with pestle and mortar and later blended into powdery form.

Portions of $10 \mathrm{~g}, 20 \mathrm{~g}, 30 \mathrm{~g}, 40 \mathrm{~g}$ and $50 \mathrm{~g}$ each were measured out from the maize root and rice husk residues (powder) and were mixed thoroughly with $5600 \mathrm{~g}$ of sterilized soil in planting pots. Each treatment was replicated five times in Completely Randomized Design. Five seeds of B. pilosa obtained from University campus were planted in each of the planting pots and was moistened daily with equal amount of distilled water at 7.00GMT.

The seeds were considered germinated upon plumule emergence and they were counted for seven days until no further emergence was observed. The speed of germination known as Coefficient of Velocity (COV) was calculated according to Kayode (2000) as:

$$
\mathrm{COV}=\frac{\mathrm{A} 1+\mathrm{A} 2+\mathrm{A} 3 \ldots \ldots \ldots . \mathrm{An} \mathrm{Tn}}{\mathrm{A} 1 \mathrm{~T} 1+\mathrm{A} 2 \mathrm{~T} 2+\mathrm{A} 3 \mathrm{~T} 3+\mathrm{AnTn}} \times 100
$$

Where:

$\mathrm{A}=$ number of seedling that emerge at a particular number of days,

$\mathrm{T}=$ number of days involved.

At three weeks after planting, the B. pilos a plants were thinned to one plant per pot leaving the most vigorous and healthier plant and the weekly height measurements were recorded for eight weeks. At the end of the eighth week, the parameters such as number of leaves at harvest, longest leaf, fresh and dry root and shoot weights were recorded. The growth parameters determined were:

(1) Leaf area according to Kayode and Otoide (2007) as;

$$
\mathrm{A}=\mathrm{L} \times \mathrm{B} \times 0.75 \times 2
$$

Where: $\mathrm{A}=$ Area of the leaf, $\mathrm{L}=$ Length of the leaf, $\mathrm{B}=$ Breath of the leaf and $0.75=\mathrm{a}$ constant

(2) Relative Growth Rate (RGR) according to Hoffmann and Porter (2002), Kayode and Tedela (2005) as

$$
\mathrm{RGR}=\frac{\operatorname{Ln} \mathrm{H}_{2}-\operatorname{Ln} \mathrm{H}_{1}}{\mathrm{~T}_{2}-\mathrm{T}_{1}}
$$

Where: $\mathrm{H}_{2}=$ final height of the plant, $\mathrm{H}_{1}=$ initial height of the plant, $\mathrm{T}_{2}=$ Final time and $\mathrm{T}_{1}=$ initial time and $\mathrm{Ln}=$ natural Log.

The plants were carefully uprooted and washed thoroughly before it was later separated into roots and shoots. The fresh weights of the roots and shoots were weighed using Electronic Top Loading Digital balance; G \& G model JJ 300Y. China. They were properly tagged kept in the Laboratory of the Department of Plant Science, Ekiti State University, Ado-Ekiti, Nigeria for three weeks to obtain the dry weights. The means from the parameters were subjected to one - way analysis of variance (ANOVA, P < 0.05) using Statistical Package for Social Sciences (SPSS) version 15 (2009) computer software. 


\section{Results}

The effects of powdered extracts from residues of maize root and rice husk on the germination percentage of $B$. pilos $a$ were shown in Table 1. The table revealed that both extracts decreased the germination of B. pilosa. The rate of decrease increased with the increase in the concentration of the extracts. Results from maize root extracts revealed that the germination percentage was $88 \%$ in the control, those of $10,20,30,40$ and $50 \mathrm{~g}$ extract concentrations were $84 \%, 80 \%, 80 \%, 24 \%$ and $20 \%$ respectively. In rice husk treated seeds, germination $\%$ was $76 \%$ in the control experiment, those of $10,20,30,40$, and $50 \mathrm{~g}$ extract concentrations were $64 \%, 64 \%, 60 \%, 56 \%$ and $52 \%$ respectively. Statistical analysis (ANOVA, $\mathrm{P}<0.05$ ) revealed that only the treatments in the 40 and $50 \mathrm{~g}$ maize root extract concentrations were significantly different from those of the control experiment. In the rice husk treated seeds, no significant difference was observed in the germination percentage of the extract treated seeds when compared to the control experiment.

Table 1. Allelopathic effects of maize root and rice husk on the germination \% of Bidens pilosa

\begin{tabular}{ccc}
\hline Treatments $(\mathrm{g})$ & Maize root & Rice husk \\
\hline 0 & $88.00 \mathrm{a}$ & $76.00 \mathrm{a}$ \\
10 & $84.00 \mathrm{a}$ & $64.00 \mathrm{a}$ \\
20 & $80.00 \mathrm{a}$ & $64.00 \mathrm{a}$ \\
30 & $80.00 \mathrm{a}$ & $60.00 \mathrm{a}$ \\
40 & $24.00 \mathrm{~b}$ & $56.00 \mathrm{a}$ \\
50 & $20.00 \mathrm{~b}$ & $52.00 \mathrm{a}$ \\
\hline
\end{tabular}

Means followed by the same letter within column are not significantly different at $\mathrm{P}<0.05$.

The effects of extracts on the speed of germination of B. pilosa were shown in Table 2. The results revealed that the speed of germination of B. pilosa seeds reduced with increase in the concentration of both extracts. The reduced speed of germination was more pronounced in maize root extracts and the degree of retardation was concentration dependent. Results from B. pilosa treated with extract from maize root showed that while the speed of germination in the control was 41.11 those of 10,20,30,40 and $50 \mathrm{~g}$ extract concentrations were 19.64, 17.87, 17.71, 17.69 and 7.45 respectively. In rice husk treated seeds, the speed of germination in the control was 20.36 , those of $10,20,40$ and $50 \mathrm{~g}$ extract concentrations were 19.63, 19.60, 19.46, 19.34 and 19.18 respectively. Statistical analyses (ANOVA, $\mathrm{P}<0.05$ ) revealed that there were significant differences in the speed of germination of B. pilosa seeds treated with maize root extracts while compared to control experiments. No significant difference was observed in rice husk treated seeds compared to control experiment.

Table 2. Allelopathic effects of maize root and rice husk on the speed of germination of Bidens pilosa

\begin{tabular}{ccc}
\hline Treatments $(\mathrm{g})$ & Maize root & Rice husk \\
\hline 0 & $41.11 \mathrm{a}$ & $20.36 \mathrm{a}$ \\
10 & $19.64 \mathrm{~b}$ & $19.63 \mathrm{a}$ \\
20 & $17.87 \mathrm{~b}$ & $19.60 \mathrm{a}$ \\
30 & $17.71 \mathrm{~b}$ & $19.46 \mathrm{a}$ \\
40 & $17.69 \mathrm{~b}$ & $19.34 \mathrm{a}$ \\
50 & $7.45 \mathrm{c}$ & $19.18 \mathrm{a}$ \\
\hline
\end{tabular}

Means followed by the same letter within column are not significantly different at $\mathrm{P}<0.05$.

The effects of extracts from residues from maize root and rice husk on the number of $B$. pilosa leaves at harvest were shown in Table 3. The results also revealed that the extracts resulted in the reduction of B. pilos $a$ leaf number. The leaf number decreased with increase in the concentration of the extracts. The reduction was more pronounced in maize root treated seeds. The results from maize root treated seeds showed that the mean leaf number in the control experiment was 44.00 , while those of $10,20,30,40$ and $50 \mathrm{~g}$ concentrations were $36.20,28.20,20.00,2.80$ 
and 1.60 respectively. Also the leaf number of $B$. pilosa treated with residues of rice husk was 93.40 in the control, those of $10,20,20,30,40$ and $50 \mathrm{~g}$ concentrations were $90.60,80.00,73.40,61.60$ and 58.80 respectively. Statistical analyses revealed that there were significant differences in the number of leaves of $B$. pilosa from seeds treated with extracts from maize root when compared to the control experiment. In rice husk extract treated seeds; there were no significant differences in the number of leaves of seedlings from the extract treated seeds when compared to the control experiment.

Table 3. Allelopathic effects of maize root and rice husk on the number of leaves of Bidens pilosa

\begin{tabular}{ccc}
\hline Treatments $(\mathrm{g})$ & Maize root & Rice husk \\
\hline 0 & $44.00 \mathrm{a}$ & $93.40 \mathrm{a}$ \\
10 & $36.20 \mathrm{ab}$ & $90.60 \mathrm{a}$ \\
20 & $28.20 \mathrm{bc}$ & $80.00 \mathrm{a}$ \\
30 & $20.00 \mathrm{c}$ & $73.40 \mathrm{a}$ \\
40 & $2.80 \mathrm{~d}$ & $61.60 \mathrm{a}$ \\
50 & $1.60 \mathrm{~d}$ & $58.80 \mathrm{a}$ \\
\hline
\end{tabular}

Means followed by the same letter within column are not significantly different at $\mathrm{P}<0.05$.

The effects of extracts on the leaf area of $B$. pilosa were shown in Table 4. The results revealed that both residues (extracts) treatments have inhibitory effects on the leaf area of $B$. pilosa. The leaf area of the treated seeds was retarded with the proportion of the retardation increasing with increase in the concentration of the extracts. The retardation was more pronounced in the seedlings from the maize root extracts treated seeds. This tends to suggest the effects were concentration dependent. The results from maize root extract treated seeds revealed that while the leaf area of $B$. pilos $a$ in the control experiment was $92.23 \mathrm{~cm}^{2}$, those of 10,20,30, 40 and $50 \mathrm{~g}$ concentrations were $90.77 \mathrm{~cm}^{2}, 83.03 \mathrm{~cm}^{2}, 42.08 \mathrm{~cm}^{2}, 22.79 \mathrm{~cm}^{2}$, and $6.30 \mathrm{~cm}^{2}$ respectively. Similarly in rice husk treated seeds, the leaf area of $B$. pilos $a$ in the control was $163.27 \mathrm{~cm}^{2}$, those of $10,20,30,40$ and $50 \mathrm{~g}$ concentrations were 159.83 $\mathrm{cm}^{2}, 146.59 \mathrm{~cm}^{2}, 132.62 \mathrm{~cm}^{2}, 124.94 \mathrm{~cm}^{2}$ and $110.70 \mathrm{~cm}^{2}$. Statistical analysis revealed that results obtained from the 40 and $50 \mathrm{~g}$ maize root extract concentrations were significantly different from those of the control experiment. No significant difference was observed in the rice husk treated seeds compared to control experiments.

Table 4. Allelopathic effects of maize root and rice husk on the leaf area of Bidens pilosa

\begin{tabular}{ccc}
\hline Treatments $(\mathrm{g})$ & Maize root & Rice husk \\
\hline 0 & $92.23 \mathrm{a}$ & $163.27 \mathrm{a}$ \\
10 & $90.77 \mathrm{a}$ & $159.83 \mathrm{a}$ \\
20 & $83.03 \mathrm{a}$ & $146.59 \mathrm{a}$ \\
30 & $42.08 \mathrm{ab}$ & $132.62 \mathrm{a}$ \\
40 & $22.79 \mathrm{~b}$ & $124.94 \mathrm{a}$ \\
50 & $6.30 \mathrm{~b}$ & $110.70 \mathrm{a}$ \\
\hline
\end{tabular}

Means followed by the same letter within column are not significantly different at $\mathrm{P}<0.05$.

The effects of extracts on the Relative Growth Rate (RGR) of B. pilosa were shown in Table 5. The RGR of B. pilosa in both extracts decreased with increase in the concentration of the extracts showing that degree of retardation were concentration dependent. For example, the RGR of B. pilosa treated with maize root had $0.42 \mathrm{~cm}$ in the control experiment, those of $10,20,30,40$ and $50 \mathrm{~g}$ concentrations were $0.42 \mathrm{~cm}, 0.42 \mathrm{~cm}, 0.35 \mathrm{~cm}, 0.30 \mathrm{~cm}$ and $0.28 \mathrm{~cm}$ respectively. Similarly, the RGR of B. pilosa treated with rice husk residues was $0.49 \mathrm{~cm}$ in the control, those of 10, 20, 30, 40, and $50 \mathrm{~g}$ concentrations were $0.49 \mathrm{~cm}, 0.47 \mathrm{~cm}, 0.45 \mathrm{~cm}, 0.44 \mathrm{~cm}$ and $0.41 \mathrm{~cm}$ respectively. Statistical analyses revealed that there were no significant in the RGR of B. pilosa seedlings from seeds treated with both extracts when compared to control experiments. 
Table 5. Allelopathic effects of maize root and rice husk on the Relative Growth Rate (RGR) of Bidens pilosa

\begin{tabular}{ccc}
\hline Treatments $(\mathrm{g})$ & Maize root & Rice husk \\
\hline 0 & $0.42 \mathrm{a}$ & $0.49 \mathrm{a}$ \\
10 & $0.42 \mathrm{a}$ & $0.47 \mathrm{a}$ \\
20 & $0.42 \mathrm{a}$ & $0.47 \mathrm{a}$ \\
30 & $0.35 \mathrm{a}$ & $0.45 \mathrm{a}$ \\
40 & $0.30 \mathrm{a}$ & $0.44 \mathrm{a}$ \\
50 & $0.28 \mathrm{a}$ & $0.41 \mathrm{a}$ \\
\hline
\end{tabular}

Means followed by the same letter within column are not significantly different at $\mathrm{P}<0.05$.

The effects of the extracts on the biomass of B. pilosa were shown in Table 6. The results obtained on the dry root and shoot weights of $B$. pilos $a$ in both residues were similar. Decreased root and shoot weights were obtained. The values decreased as the concentration of the extracts increases. In maize root treated seeds, the dry root weight of $B$. pilosa in the control experiment was $1.00 \mathrm{~g}$, which decreased to $0.22 \mathrm{~g}$ in $50 \mathrm{~g}$ concentration. Similarly, the dry shoot weights decreased from $2.82 \mathrm{~g}$ in the control to $0.14 \mathrm{~g}$ in $50 \mathrm{~g}$ concentration. Also, in rice husk treated seeds, the dry root weight of B. pilosa decreased from $0.82 \mathrm{~g}$ in the control to $0.46 \mathrm{~g}$ in the $50 \mathrm{~g}$ extract concentration. Similarly, the dry shoot weight decreased from $7.30 \mathrm{~g}$ in the control to $6.00 \mathrm{~g}$ in the $50 \mathrm{~g}$ concentration. Statistical analyses revealed that the values obtained in the 40 and $50 \mathrm{~g}$ extract concentrations of both the root and shoot weights of maize root treated seeds were significantly different from the control experiments. However, no significant different was observed in both root and shoot weights of rice husk treated seeds when compared to the control experiments.

Table 6. Allelopathic effects of crop residues on the Dry Root and Shoot weights of Bidens pilosa

\begin{tabular}{ccccc}
\hline $\begin{array}{c}\text { Treatments } \\
(\mathrm{g})\end{array}$ & \multicolumn{2}{c}{ Maize root } & \multicolumn{2}{c}{ Rice husk } \\
& $\mathrm{R}$ & $\mathrm{S}$ & $\mathrm{R}$ & $\mathrm{S}$ \\
\hline 0 & $1.00 \mathrm{a}$ & $2.82 \mathrm{a}$ & $0.82 \mathrm{a}$ & $7.30 \mathrm{a}$ \\
10 & $0.80 \mathrm{a}$ & $2.64 \mathrm{a}$ & $0.76 \mathrm{a}$ & $6.68 \mathrm{a}$ \\
20 & $0.72 \mathrm{a}$ & $2.06 \mathrm{a}$ & $0.64 \mathrm{a}$ & $6.42 \mathrm{a}$ \\
30 & $0.22 \mathrm{a}$ & $2.02 \mathrm{a}$ & $0.62 \mathrm{a}$ & $6.06 \mathrm{a}$ \\
40 & $0.06 \mathrm{a}$ & $0.20 \mathrm{~b}$ & $0.60 \mathrm{a}$ & $6.00 \mathrm{a}$ \\
50 & $0.22 \mathrm{c}$ & $0.14 \mathrm{~b}$ & $0.46 \mathrm{a}$ & $6.00 \mathrm{a}$ \\
\hline
\end{tabular}

Means followed by the same letter within column are not significantly different $\mathrm{Pt}<0.05$.

\section{Discussion}

It was observed that the extract from the maize root demonstrated more inhibitory effects on most of the growth parameters such as number of leaves and leaf area, relative growth rate, root and shoot weights as well as the relative growth rate of $B$. pilos $a$ examined in this study. This tends to suggest the suitability of the extract from the maize root residues as as bio herbicides in the control of weeds.

Previous assertion by Salam et al. (2009) suggested that extracts from rice husk contain growth inhibitory substances that limit the root and shoot growth elongation of E. grucigalli. Also, Oyun (2006) reported that the root and shoot lengths and seedling index of maize were decreased with increasing concentration of Gliricidia sepium. The number of leaves and leaf areas in seedling of the extract treated seeds decreased with increase in the concentration of the extracts. This corroborated the work of Yarnia 2009 that the number of leaves and leaf areas of extract treated seeds decreased with increase in the concentration of the extracts. This tends to suggest that the physiological activities of the extract treated weeds decreased as the concentration of the extract increases. The allelochemicals produced from the crop residues might be responsible for the inhibitory effects observed in this 
study. Previous study by Sanchez-Moreiras et al. (2004) had revealed that maize inflorescence contained hydroxamic acid. Also, Eihnellig and Souza (1992) revealed that maize root exudates are mostly saponin that is extremely phytotoxic while Chou and Lin (1976) asserted that rice husks contained chemicals such as P-hydroxyl benzoic acid, syringic acid, vallinic, ferrullic, acetic-o-hydroxyl Phenyl acetic, propionic and butyric acids. All these chemical compounds (allelochemicals) might be responsible for the inhibition of B. pilosa shown in this study.

\section{References}

Ahmad, S., Arfan, M., Khan, A. L., Ullah, R., Hussain, J., Muhammad, Z., ... Watanabe, N. (2011). Allelopathy of Teucrium royleanum Wall. Ex. Benth. Pakistan J. Med. Plants. Res., 5(5), 765-772.

Ayeni, A. O., Lordbanjou, D. T., \& Majek, B. A. (1997). Tithonia diversifolia (Mexican sunflower) in South Western Nigeria. Occurrence and growth habit. Weed Res., 37(6), 443-449. http://dx.doi.org/10.1046/j.1365-3180.1997.d01-72.x

Ayeni, J. M., Kayode, J., \& Tedela, P. O. (2010). Allelopathic Potentials of Some Crop Residues on the Germination and Growth of Bidens pilosa L. J. Agri. Sci. Tech., 4(1), 21-24.

Ayeni, M. J., \& Kayode, J. (2011). Allelopathic Potentials of Some Crop Residues on the Germination and Seedling Growth of Chromolaena odoratum L. J. Sci., 5(3), 220-223.

Ben, H. M., Hebit, G., Kremer, R. J., \& Quassama, O. (2001). Allelopathic effects of barley extracts on germination and seedlings growth of bread and durum wheat. Agrono., 21, 65-71. http://dx.doi.org/10.1051/agro:2001109

Calera, M. R, Mata, R., Anaya, A. L., \& Lotina-Hennsen, B. (1995). 5-O-B-D- galactopyranosy 1-7-methoxy- 34 dihydroxi-4- fenilcumarin, an inhibitor of photophosphorylation in spinach chloroplasts. Photosynth. Res., 45 , 105-110. http://dx.doi.org/10.1007/BF00032581

Chaves, N., \& Escudero, C. (2006). Effect of Allelopathic compounds produced by Cisius ladenien on germination of 20 Mediterrariean taxa. Plant Ecol., 184, 259-272. http://dx.doi.org/10.1007/s11258-005-9071-6

Chuo, C. H., \& Lin, H. J. (1976). Auto intoxication mechanism of Oryza sativa L. Phytotoxic effects of decomposing rice residues in soil. J. Chem. Ecol., 2, 353-367. http://dx.doi.org/10.1007/BF00988282

Einhellig, F. A., \& Souza, I. F. (1992). Phytotoxicity of Sorgoleone formed in grain Sorghum root exudates. J. Chem. Ecol., 18, 1-11. http://dx.doi.org/10.1007/BF00997160

Galindo, J. C. G., Hernandez, A., Dayan, F. E., Tellez, M. R., Marcias, F. A., Paul, R. N., \& Duke, S. O. (1999). Dehydrozaluzanin C. a natural ses-quiterpenolide, causes rapid plasma membrane leakage. Phytochem, 52, 805-813. http://dx.doi.org/10.1016/S0031-9422(99)00303-9

Gill, L. S., Anoliefo, G. O., \& Iduoze, U. V. (1993). Allelopathic effect of aqueous extracts from Siam weed on growth of cowpea. Chromo. Newsl., 8, 1-11.

Hoffmann, W. A., \& Porter, H. (2002). Avoiding Bias in Calculating Relative Growth Rate. Ann, Bot., 90(1), 37. http://dx.doi.org/10.1093/aob/mcf140

Kayode, J. (2000). A study of seed stock in rainforest site in Ado Ekiti region, Nigeria. Biosci. Res. Comm., 12(3), 325-339.

Kayode, J. (2004a). Allelopathic effects of aqueous extracts of Aspillia africana on radicle and plumule growth of Zea mays. J. Physic. Biolog. Sci., 2, 43-46.

Kayode, J. (2004b). Allelopathic effects of aqueous extracts of Calotropis procera on germination and seedling growth of maize. Pak. J. Sci. Ind. Res., 47(1), 69-72.

Kayode, J., \& Otoide, J. E. (2007). Leaf cuticle variation in Amaranthus spinosus as indicators of environmental pollution. Pak. J. Sci. Ind. Res., 50(5), 327-329.

Kayode, J., \& Tedela, P. O. (2005). Effects of irrigation frequency on growth and nodulation of Leucaena leucocephala. Pak. J. Forest., 554(1), 33-40.

Kayode. J., \& Adanlawo, I. G. (1997). Allelopathic effects of aqueous extracts of Euphorbia heterophylla on radicle and plumule growth of cowpea (Vigna unguiculata) Walp. Biosci. Res. Comm., 10, 23-26.

Khanh, A. L., Hamayun, M., Hussain, J., Khan, H., Gilani, S. A., Kukuchi, A., ... Lee, J. (2009). Assessment of allelopathic potential selected medicinal plants of Pakistan. Afr. J. Biot., 8(6), 1024- 1029. 
Khanh, T. D., Xuan, T. D., \& Chung, M. (2007). Rice allelopathy and the possibility for weed management: Annals of Appl. Biol., 151, 325-339. http://dx.doi.org/10.1111/j.1744-7348.2007.00183.x

Oyun, M. B. (2006). Allelopathic potentials of Gliricidia sepium and Acacia auriculiformis on the germination and seedling vigour of maize (Zea mays L). Amer. J. Agric. Biolog. Sci., 1(3), 44-47. http://dx.doi.org/10.3844/ajabssp.2006.44.47

Qussama, O. (2003). Allelopathy in two durum wheat (Tritium durum L.) varieties. Agric. Econs. Environ., 96, 161-163. http://dx.doi.org/10.1016/S0167-8809(02)00201-3

Rice, E. L. (1984). Allelopathy. Academic Press, New York, USA.

Ridenour, W. M., \& Callaway, R. M. (2001). The relative importance of allelopathy in interference: the effects of invasive weed on native bunchgrass. Oecolog., 126, 444-450. http://dx.doi.org/10.1007/s004420000533

Salam, M. A., Morokuma, M., Teruya, T., Seunega, K., \& Kato- Noguchi, H. (2009). Isolation and identification of a potent allelopathic substances in Bangladesh rice. Plant Growth Regul., 58, 137-140. http://dx.doi.org/10.1007/s10725-009-9360-5

Sanchez-Moreiras, A. M., Tloba de la p., Martinez, A., Gonzalez, L., Pellisier, F., \& Regiosa, M. J. (2004). Mode of action of hyrdroxamic acid (BOA) and otherrelated compounds. In J. C. G. Galindo, F. A. Macias, \& J. M. Gonzalez (Eds.), Allelopathy; Chemistry and mode of action of allelochemicals (pp. 239-252). New York: CRS Press.

Tijani-Eniola, H. A., \& Fawusi, O. A. (1989). Allelopathic activities of crude methanol extracts of Siam weed and wild poinsettia on seed germination and seedling growth of tomato. Nig. J. Weed Sci., 2, 15-20.

Yarnia, M., Khorshidi-Benan, M. B., \& Farajzadeh, M. T. E. (2009). Allelopathic effects of sorghum extracts on Amaranthus retroflexus seed germination and growth. J. Food Agri. Environm., 7(3\&4), 770-774. 